DOI: 10.18276/sip.2016.43/2-26

\title{
Katarzyna Sanak-Kosmowska*
}

\section{CROWDSOURCING JAKO FORMA WDRAŻANIA INNOWACJI W ŚRODOWISKU INTERNETOWYM}

\begin{abstract}
STRESZCZENIE
Artykuł przedstawia koncepcję crowdsourcingu oraz przykłady jego wykorzystania przez organizacje poszukujące innowacyjnych rozwiązań poprzez angażowanie $\mathrm{w}$ ten proces konsumentów. W szczególności scharakteryzowane zostaną takie pojęcia, jak inteligencja zbiorowa, mądrość tłumu oraz wirtualne społeczności, leżące u podstaw wykorzystania crowdsourcingu do rozwoju innowacyjności organizacji. W drugiej części artykułu przedstawione zostaną analizy przypadków, stanowiące przykłady dobrych praktyk ilustrujących wykorzystanie crowdsourcingu, zarówno uzasadnienie tezy głoszącej, że crowdsourcing stanowi skuteczną formę komunikacji z konsumentami i pozyskiwania nowych koncepcji rozwoju, jak i tego, że środowisko internetowe stwarza ku temu odpowiednie warunki.
\end{abstract}

Słowa kluczowe: crowdsourcing, mądrość tłumu, inteligencja zbiorowa, społeczności wirtualne, innowacje

\section{Wprowadzenie}

„Brak innowacji w firmie wskazuje albo na to, że nie potrafi ona systematycznie wyszukiwać i badać nowych okazji, albo na to, że inwestuje w wiele nowych okazji przynoszących niezadowalające wyniki” (Kotler, 2005, s. 72). Autor powyższego stwierdzenia podkreśla, że brak innowacji i otwarcia przedsiębiorstwa na zmiany stanowi jeden z ,grzechów głównych” organizacji i zmniejsza ich szanse na sukces.

* Uniwersytet Ekonomiczny w Krakowie, adres e-mail: sanakk@uek.krakow.pl. 
Obecnie coraz więcej przedsiębiorstw wchodzi na ścieżkę „otwartych innowacji” czy też crowdsourcingu, angażując w proces poszukiwania kreatywnych rozwiązań osoby i podmioty z otoczenia.

Celem prezentowanego artykułu jest przybliżenie istoty crowdsourcingu jako innowacyjnej formy poszukiwania nowych rozwiązań. Wskazane zostaną również zjawiska społeczne leżące u podstaw wspomnianego procesu. W dalszej części artykułu przeprowadzona zostanie analiza przykładów skutecznego wdrożenia crowdsourcingu w proces adaptacji innowacji w wybranych przedsiębiorstwach, zarówno tych, które zdecydowały się na skorzystanie z gotowych platform crowdsourcingowych, jak i tych, które stworzyły własne narzędzia. Pozwoli ona na weryfikację tezy głoszącej, że crowdsourcing stanowi skuteczną formę komunikacji z konsumentami i pozyskiwania nowych koncepcji rozwoju, środowisko internetowe zaś stwarza ku temu odpowiednie warunki, bez względu na wielkość przedsiębiorstwa i prowadzoną przez niego działalność.

\section{Innowacyjna organizacja w środowisku Web 3.0}

W jednej z swoich książek Kotler określa ostatnie lata jako erę „,współuczestnictwa i marketingu kooperacyjnego", prowadzące do powstania epoki marketingu 3.0 (Kotler, 2010, s. 23). Jego zdaniem główną siłą napędową tej zmiany stanowią technologie nowej fali, które począwszy od 2000 roku przenikają i dominują główne rynki wymiany gospodarczej. Według Grudzewskiego i Hejduka to dzięki wdrażaniu innowacji następuje poprawa i unowocześnienie procesów produkcji, wydajności i jakości pracy, wzrost konkurencyjności i zlikwidowanie barier (Grudzewski, Hejduk, 2001, s. 451-452).

W opinii Pomykalskiego źródłem innowacji może być wszystko, co inspiruje człowieka do procesu zmian. Literatura przedmiotu przedstawia podział źródeł innowacji na wewnętrzne i zewnętrzne (Pomykalski, 2001, s. 25-27):

- źródła endogeniczne (wewnętrzne) - pochodzą z wnętrza przedsiębiorstwa; autorami innowacji może być dział badań i rozwoju, pracownicy czy też kadra kierownicza;

- źródła egzogeniczne (zewnętrzne) - opierają się na informacjach od klientów, dostawców i konkurentów oraz na współpracy z takimi instytucjami, jak: placówki naukowo-badawcze, naukowo-rozwojowe, a także zwiększają innowacyjność przez zakup licencji lub know-how. 
Tabela 1. Przegląd definicji innowacji

\begin{tabular}{|c|c|}
\hline Autor & Definicja \\
\hline R. Griffin (1996) & $\begin{array}{l}\text { Kierowany wysiłek organizacji na rzecz opanowania nowych produktów } \\
\text { i usług lub nowych zastosowań tych istniejących już wcześniej }\end{array}$ \\
\hline T. Amabile (1996) & Pomyślna implementacja kreatywnych pomysłów \\
\hline Z. Pietrusiński (1997) & $\begin{array}{c}\text { Zmiany celowo wprowadzane przez człowieka, zaprojektowane przezeń układy } \\
\text { cybernetyczne, które polegają na zastępowaniu istniejących innymi, ocenianymi } \\
\text { dodatnio w świetle określonych kryteriów }\end{array}$ \\
\hline S. Gomułka (2000) & Akt jakościowej zmiany w gospodarce, kiedy zaczyna się produkcja nowego wyrobu \\
\hline S. Marciniak (2000) & $\begin{array}{l}\text { Twórcze zmiany w systemie społecznym, strukturze gospodarczej, } \\
\text { technice oraz przyrodzie }\end{array}$ \\
\hline $\begin{array}{l}\text { W.M. Grudzewski, } \\
\text { I.K. Hejduk (2000) }\end{array}$ & Każda myśl, zachowanie lub rzecz, która jest nowa, czyli różna od form istniejących \\
\hline A. Pomykalski (2001) & $\begin{array}{l}\text { Proces obejmujący całość działań związanych z kreowaniem pomysłu } \\
\text { oraz jego wdrażaniem }\end{array}$ \\
\hline $\begin{array}{l}\text { Podręcznik } \\
\text { Oslo (2005) }\end{array}$ & $\begin{array}{c}\text { Wdrożenie nowego lub istotnie ulepszonego produktu (wyrobu lub usługi), nowego } \\
\text { lub istotnie ulepszonego procesu, nowej metody marketingu lub nowej metody } \\
\text { organizacji w zakresie praktyk biznesowych, organizacji miejsca pracy bądź relacji ze } \\
\text { środowiskiem zewnętrznym }\end{array}$ \\
\hline
\end{tabular}

Źródło: opracowanie własne na podstawie: Griffin, 1996, s. 476; Amabile, 1996, s. 187; Grudzewski, Hejduk, 2008, s. 34; Pomykalski, 2001, s. 10-15; Gomułka, 1998, s. 17-20; Marciniak, 2000, s. 11-18; Podręcznik Oslo, 2005.

Wspominając o innowacjach, których geneza sięga źródeł zewnętrznych, nie można pominąć koncepcji „otwartych innowacji” (open innovations) autorstwa Chesbrougha. Autor przekonuje, że obecnie nie jest możliwe prowadzenie działań badawczych samodzielnie przez firmę. Dzięki nowoczesnym technologiom, a w szczególności rozwojowi internetu i technologii Web 3.0 (wcześniej Web 2.0) owo „współprowadzenie" działań badawczych staje się prostsze i bardziej efektywne.

\section{Koncepcja crowdsourcingu}

Termin crowdsourcing został po raz pierwszy użyty przez Howe’a w 2006 roku w amerykańskim czasopiśmie „Wired” (Howe, 2006). Autor określił go jako różne formy współpracy przedsiębiorstwa z internautami, przy wykorzystaniu ich wiedzy, umiejętności i pomysłów.

Próbę zdefiniowania crowdsourcingu, przeprowadzoną na podstawie analizy ponad 40 propozycji definicji dostępnych w literaturze przedmiotu, podjęli Estellés-Arolas oraz Gonzalez-Ladron de Guevara (2012, s. 189-200). Autorzy okre- 
ślili to zjawisko jako rodzaj partycypacyjnej działalności internetowej, w ramach której podmiot indywidualny, instytucja, organizacja non profit lub też przedsiębiorstwo proponuje grupie osób przez otwarte zaproszenie i dobrowolne podjęcie się realizacji określonego zadania. Satysfakcja podmiotu realizującego zadanie może być typowo ekonomiczna (finansowa), społeczna (rozpoznawalność), indywidualna (wzrost poczucia własnej wartości, rozwój umiejętności). Z kolei podmiot zlecający zadanie uzyskuje rozwiązanie zleconego problemu (Adamska-Mieruszewska, Mrzygłód, 2012, s. 1-14).

Zdaniem Howe'a (2006) crowdsourcing może przejawiać się na kilka sposobów, np. jako:

- wspólne rozwiązywanie problemów i proponowanie udoskonaleń przy udziale inteligencji zbiorowej,

- korzystanie z tzw. mądrości tłumu, a w tym szczególnym przypadku korzystanie z potencjału internautów,

- mikropraca,

- społeczne finansowanie projektów (crowdfounding),

- analiza i wybór najlepszych rozwiązań z zaprezentowanych propozycji.

U podstaw założeń wspomnianej teorii mądrości tłumu leży przekonanie, że zbiorowe rozwiązywanie problemu przez grupę osób zapewnia lepsze rezultaty niż wykorzystanie kreatywności poszczególnych jednostek. Zdaniem Surowieckiego, autora tej koncepcji, źródłem przewagi „tłumu” nie jest osiągnięcie konsensusu, ale agregacja pomysłów poszczególnych uczestników danej grupy przez wykorzystanie ich proaktywności, kreatywności i niezależności (Surowiecki, 2010, s. 29-55)ํ․

Z pojęciem mądrości tłumu wiąże się również koncepcja inteligencji zbiorowej, którą w społeczności wirtualnej powołał do życia Lévy, definiując jako: „wszelką grupę ludzką nie tyleż mającą interes w tworzeniu wspólnoty wirtualnej, co zbliżającą się do ideału zbiorowej inteligencji, bardziej pomysłową, szybszą, zdolniejszą do nauczania się, wymyślania niż kolektyw inteligentnie prowadzony (Lévy, 1997, za: Jenkins, 2006, s. 31).

1 Howe wskazuje na następujące czynniki wpływające na rozwój koncepcji mądrości tłumu: aktywność pasjonatów, zwiększenie popularności koncepcji „otwartego programowania”, powstanie społeczności internetowych (Howe, 2008, s. 17-18). 


\section{Crowdsourcing w środowisku internetowym - dobre praktyki}

W niniejszym rozdziale przedstawione zostaną przykłady dobrych praktyk z obszaru crowdsourcingu. W pierwszej kolejności zaprezentowane zostaną wybrane portale internetowe służące wymianie idei $\mathrm{w}$ duchu koncepcji crowdsourcingu (tabela 2) ${ }^{2}$. Przedsiębiorstwa oraz osoby fizyczne, chcące zrealizować swój projekt lub rozwiązać problem przy udziale innych internautów, mogą bowiem zarejestrować się w jednym $\mathrm{z}$ serwisów służących takim celom. Zdecydowaną zaletą $-\mathrm{z}$ punktu widzenia przedsiębiorstwa - jest możliwość skorzystania z gotowego narzędzia, bez konieczności inwestowania nakładów pracy i czasu w celu stworzenia własnej platformy. Serwisy te umożliwiają przedsiębiorstwom dodanie projektu, moderowanie prowadzonych prac, przeglądanie proponowanych rozwiązań oraz nagradzanie tych, których pomysły okażą się najlepsze. Gotowe serwisy crowdsourcingowe zapewniają także dostęp do użytkowników (zarejestrowanych w serwisie) i ułatwiają rekrutację do projektu - w przypadku własnej platformy barierą wejścia może się okazać brak zainteresowania ze strony internautów. Wśród minusów takiego rozwiązania należy podkreślić ograniczenia techniczne, jakie narzucają serwisy - w większości przypadków nie istnieje możliwość pełnego dopasowania funkcjonalności do własnych potrzeb. Innym problemem może okazać się kwestia innowacyjności i oryginalności proponowanych rozwiązań - użytkownicy serwisów mogą bowiem pracować nad kilkoma projektami równocześnie, a w skrajnym przypadku również nad pomysłami konkurencji. To rodzi również wątpliwości dotyczące ochrony know-how i tajemnic firmowych przedsiębiorstwa.

2 Jakościowe badania poświęcone motywom użytkowników platform crowdsourcingowych w modelu agencji marketingowych przeprowadził Kreft. Jego zdaniem oczekiwania firm i użytkowników są zazwyczaj odmienne. Ponadto, jak wynika z badania motywów użytkowników, większość platform crowdsourcingowych jest niczym więcej niż miejscami spotkań nabywców z zamawiającymi rozwiązania problemów (Kreft, 2015, s. 1523-1528.) 
Tabela 2. Wybrane serwisy crowdsourcingowe

\begin{tabular}{|c|c|c|}
\hline $\begin{array}{l}\text { Nazwa } \\
\text { serwisu }\end{array}$ & $\begin{array}{c}\text { Kraj } \\
\text { pochodzenia }\end{array}$ & Ogólna charakterystyka \\
\hline NineSights & USA & 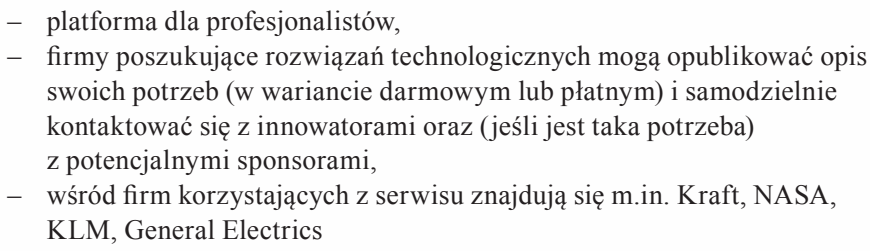 \\
\hline Sprinet & Polska & $\begin{array}{l}\text { - platforma pozwalająca na wykorzystanie zjawiska „internetowej } \\
\text { burzy mózgów”, } \\
\text { - } \\
\text { serwis umożliwia użytkownikom dodawanie pomysłów na innowacje, } \\
\text { a firmom na publikowanie problemów i projektów do rozwiązania }\end{array}$ \\
\hline Corton & Polska & $\begin{array}{l}\text { - } \text { platforma dla grafików amatorów i profesjonalistów, } \\
\text { - } \text { serwis pozwala na zgłaszanie konkursów na wykonanie projektów } \\
\text { graficznych wraz z ustaleniem budżetu na nagrody, } \\
\text { - }\end{array}$ \\
\hline
\end{tabular}

Źródło: opracowanie własne.

Przedsiębiorstwa mogą również zdecydować się na założenie własnego serwisu internetowego przeznaczonego dla projektów crowdsourcingowych, czego przykładem są m.in. następujące firmy:

1. Procter \& Gamble - korporacja uruchomiła projekt Connect + Develop, platformę, przy pomocy której specjaliści z wybranych dziedzin mogą dodawać swoje oryginalne pomysły na innowacje. Zgłaszane projekty muszą spełniać kryteria stawiane przez firmę: pomysł musi dotyczyć jednego z obszarów, w którym firma aktualnie się rozwija (w listopadzie 2015 roku na owej liście znajdowały się m.in.: poszukiwanie nowych technologii dla produktów służących goleniu, zbieranie pomysłów na nowatorskie opakowania produktów, poprawa komunikacji z klientami), technologie muszą być opatentowane, a osoba je oferująca musi być ich prawnym właścicielem. Serwis ten jest zatem skierowany do profesjonalistów: badaczy, wynalazców i projektantów, którzy mogą swoje projekty „,sprzedać” korporacji. Wśród projektów zrealizowanych przy wykorzystaniu Connect + Develop można wymienić m.in.: nową szczoteczkę tuszu do rzęs Covergirl (zaprojektowaną i zgłoszoną przez firmę Geka), opakowania szamponu Pantene z biodegradowalnego plastiku (wynalezionego przez brazylijską firmę Braskem) oraz szczoteczkę do zębów Pulsonic o innowacyjnym działaniu, zaprojektowaną wspólnie z japońską firmą. 
2. Starbucks - jedna z najpopularniejszych sieci kawiarni na świecie uruchomiła własny serwis o nazwie My Starbucks Idea. Platforma skierowana jest do konsumentów - klientów kawiarni, którzy mają pomysły na zmiany, ulepszenia czy też promocje konsumenckie. W tym przypadku od rejestrujących się użytkowników nie wymaga się niczego więcej poza podaniem danych osobowych umożliwiających dodawanie pomysłów oraz ocenianie i komentowanie innych projektów. Wśród zrealizowanych koncepcji można wymienić m.in.: wprowadzenie do kawiarni dań bezglutenowych o dużej wartości kwasów omega, opracowanie nowej receptury jednej z serwowanych kaw, wprowadzenie szklanych butelek wielorazowego użytku i zmianę oświetlenia we wszystkich kawiarniach na żarówki LED.

3. Heineken - projekt Heineken Innovators Brewhouse został stworzony przez korporację w celu pozyskiwania kreatywnych pomysłów na innowacje od partnerów: innych przedsiębiorstw, wynalazców, jednostek akademickich, partnerów biznesowych oraz piwoszy, którzy chcieliby podzielić się swoimi pomysłami na zmiany. Obecnie Heineken zawęża obszar poszukiwania innowacji do obszaru technologii, opakowań oraz kultury serwowania produktów.

4. Kraft - korporacja działająca w branży spożywczej korzysta $\mathrm{z}$ crowdsourcingu na dwa sposoby. Przez wspomniany wcześniej serwis NineSights zaprasza do współpracy profesjonalistów: technologów żywienia i naukowców specjalizujących się w branży spożywczej. Natomiast bezpośrednio przez stronę Kraft Foods (poprzez formularz zgłoszeniowy) swoimi pomysłami, przepisami i propozycjami zmian mogą podzielić się również internauci-amatorzy. Ciekawym przykładem realizacji pomysłu współtworzonego przez konsumentów był film promocyjny czekolady Lacta, przygotowany na rynek grecki dla jednej z marek Kraft Foods. Internauci zostali zaangażowani w proces tworzenia reklamy już od samego początku - od napisania scenariusza przez dobór muzyki (poprzez ankiety on-line) aż do wyboru obsady oraz ich filmowych imion i charakteryzacji (Hall, 2015).

\section{Podsumowanie}

Przedstawione w niniejszym artykule przykłady wdrażania innowacji przez wykorzystanie crowdsourcingu potwierdzają tezę, że omawiane zjawisko stanowi skuteczne narzędzie komunikacji i współpracy z internautami. Należy podkreślić, 
że z crowdsourcingu korzysta również wiele mniejszych przedsiębiorstw, zachęcając swoich klientów zarówno do zgłaszania pomysłów na ulepszenia, projektów własnych „szytych na miarę” produktów, jak i poszukujących profesjonalistów do współpracy ${ }^{3}$. Rozwiązania bazujące na „otwartej innowacji” stają się coraz bardziej dostępne dzięki rozwojowi technologii Web 3.0: przedsiębiorstwa mogą obecnie korzystać z nich bez względu na wielkość i obszar oraz zakres działania. Duży wybór platform internetowych poświęconych współtworzeniu innowacji przez internautów oraz możliwość implementacji własnych narzędzi sprawiają, że crowdsourcing może być rozumiany jako niezwykle istotne zewnętrzne źródło innowacji. Powołując się na Raport Massolution, można przewidzieć szybki wzrost znaczenia platform tego typu, mających na celu „dostarczanie tańszej, szybciej i lepiej wykonywanej pracy” (Massolution, 2013). Przykłady przedstawione w niniejszym artykule wskazują również na szeroki zakres współpracy z konsumentami on-line - przedsiębiorstwo może zachęcać klientów do samodzielnego zgłaszania pomysłów na innowacje (jak w przypadku Starbucks), dbając przy okazji o relacje z nimi i ich opinie na temat produktów, lub też poszukiwać innowacyjnych rozwiązań konkretnych problemów. Owa różnorodność zastosowań sprawia, że crowdsourcing - odpowiednio zastosowany - może pobudzać innowacyjność przedsiębiorstw działających w różnych branżach, nie tylko tych związanych z nowoczesnymi technologiami.

Kluczowym czynnikiem sukcesu crowdsourcingu jako źródła innowacji czego ilustrację stanowią przykłady przytoczone w niniejszym artykule - jest właściwe rozpoznanie i wykorzystanie potencjału internautów angażujących się w działania crowdsourcingowe. Stworzenie dla nich odpowiedniej motywacji i wartości, bez względu na to, czy są to codzienni użytkownicy, czy naukowcy oferujący swoje patenty, może zapewnić powodzenie działań tego typu oraz zredukowanie zagrożeń, jakie może generować korzystanie z crowdsourcingu. Zdaniem Brabhama wraz $\mathrm{z}$ udoskonalaniem wspomnianych w niniejszym artykule platform crowdsourcingowych korzystanie z nich stanie się dla współczesnych przedsiębiorstw naturalnym kanałem współpracy i relacji z otoczeniem, którego przykładami są obecnie firmy consultingowe, dystrybutorzy czy firmy logistyczne (Brabham, 2013, s. 102-103).

3 Przykładami polskich firm umożliwiających projektowanie własnych produktów on-line są m.in.: producent biżuterii Lilou oraz producent obuwia LOFT37. 


\section{Literatura}

Adamska-Mieruszewska, J., Mrzygłód, U. (2014). Wykorzystanie finansowania społecznościowego w Polsce w latach 2011-2014. Zeszyty Naukowe Uniwersytetu Szczecińskiego $n r$ 804, Finanse, Rynki Finansowe, Ubezpieczenia, 67, 1-14.

Amabile, T. (1996). Creativity in Context. Boulder: WEstview Press.

Brabham, D. (2004). Crowdsourcing. Cambridge (Massachusetts): The MIT Press Essential Knowledge Series.

Corton - serwis crowdsourcingowy. Pobrane z: http://corton.pl/ (26.01.2016).

Drucker, P.F. (1992). Innowacja i przedsiębiorczość. Praktyka i zasady. Warszawa: Wydawnictwo Ekonomiczne.

Estellés-Arolas, E., Gonzalez-Ladron-de-Guevara, F. (2012). Towards an Integrated Crowdsourcing Definition. Journal of Information Science, 38 (2), 189-200.

Gomułka, S. (1998). Teoria innowacji i wzrostu gospodarczego. Warszawa: Wydawnictwo CASE.

Griffin, R. (1996). Podstawy zarzadzania organizacjami. Warszawa: PWN.

Grudzewski, P., Hejduk, I. (2001). Projektowanie systemów zarządzania. Warszawa: Difin.

Hall, E. (2015). In Greece, Kraft Scores a Hit for LactaChocolate With Crowdsourced Film, crowdsourcing.org. Pobrane z: http://goo.gl/LbpHzd (26.01.2016).

Howe, J. (2006). The rise of crowdsourcing, The Wired. Pobrane z: http://www.wired. com/2006/06/crowds/ (26.01.2016).

Howe, J. (2008). Crowdsourcing. Why the Power of the Crowd is Driving the Future of Business. New York: Three Rivers Press.

Innovations Brewhouse. Pobrane z: http://goo.gl/lp7T6V. (25.01.2016).

Jenkins, K. (2007). Kultura konwergencji. Zderzenie starych i nowych mediów. Warszawa: Wydawnictwa Akademickie i Profesjonalne.

KickStarter. Pobrane z: https://www.kickstarter.com/ (25.01.2016).

Kotler, P. (2005). 10 śmiertelnych grzechów marketingu. Warszawa: Polskie Wydawnictwo Ekonomiczne.

Kotler, P., Kartajaya, H., Setiawan, I. (2010). Marketing 3.0. Warszawa: MT Biznes.

Kreft, J. (2015). Crowdsourcing a marketing: model biznesu agencji marketingowej i czynniki krytyczne sukcesu. Logistyka, 2, 1523-1528.

Marciniak, S. (2000). Innowacje i rozwój gospodarczy. Warszawa: Kolegium Nauk Społecznych i Administracji Politechniki Warszawskiej.

Massolution Report. The Crowd in the Cloud: Exploring the Future of Outsourcing. Pobrane z: http://www.lionbridge.com/files/2012/11/Lionbridge-White-Paper_The-Crowd-in-the-Cloud-final.pdf (31.01.2016).

My Starbucks Idea. Pobrane z: http://mystarbucksidea.force.com/ (23.01.2016).

Serwis NineSights. Pobrane z: https://ninesights.ninesigma.com/ (23.01.2016).

P\&G Develop. Pobrane z: http://www.pgconnectdevelop.com/ (23.01.2016). 
Podręcznik Oslo (2005). Zasady gromadzenia i interpretacji danych dotyczacych innowacji. Pobrane z: http://www.uwm.edu.pl/ciitt/wp-content/uploads/2013/10/Podrecznik-OSLO-MANUAL1.pdf (19.01.2016).

Pomykalski, A. (2001). Zarzadzanie innowacjami. Warszawa-Łódź: PWN.

Serwis Sprinet. Pobrane z: http://sprinet.pl/ (23.01.2016).

Surowiecki, J. (2010). Mądrość tlumu. Większość ma rację w ekonomii, biznesie i polityce. Gliwice: Helion.

\title{
CROWDSOURCING AS A FORM OF THE INNOVATION'S IMPLEMENTATION ONLINE
}

\begin{abstract}
The article presents the concept of crowdsourcing and examples of its use by organizations seeking innovative solutions by engaging in the process of consumers. In particular, it will explain such concepts as innovations, crowdsourcing, collective intelligence and the wisdom of the crowd underlying the use of crowdsourcing to develop an innovative organization. The second part of the article presents case studies as examples of good practice to illustrate the use of crowdsourcing in business. The purpose of this article is to examine thesis that crowdsourcing is an effective form of communication with consumers and winning new concept of business development.
\end{abstract}

Translated by Katarzyna Sanak-Kosmowska

Keywords: crowdsourcing, the wisdom of the crowd, collective intelligence, virtual society, innovations

JEL Codes: O35 